\title{
Statistical and Trend Analysis of Climate Data of Bapatla (A.P), India
}

\author{
Saurav Srichandan Dash ${ }^{1 *}$ and H.V. Hema Kumar ${ }^{2}$ \\ ${ }^{1}$ Indian Institute of Technology, Kharagpur, West Bengal, India \\ ${ }^{2}$ CAE, Bapatla, Andhra Pradesh, India \\ *Corresponding author
}

\begin{tabular}{|c|c|}
\hline \multicolumn{2}{|r|}{ A B S T R A C T } \\
\hline & \multirow{6}{*}{$\begin{array}{l}\text { The daily weather data of } 20 \text { years were collected from the IMD Bapatla. Using daily } \\
\text { rainfall, relative humidity, maximum temperature and minimum temperature data o } \\
\text { twenty years from } 1991-2010 \text { were analysed. The data were also analysed to find out the } \\
\text { standard deviation and coefficient of variation during period of study. Coefficient o } \\
\text { variation in seasonal rainfall was } 41.71 \% \text { for kharif season, } 87.2 \% \text { for zaid and } 40.9 \% \text { for } \\
\text { Rabi season. The trend analysis of annual rainfall during } 1991 \text { to } 2010 \text { revealed that annua } \\
\text { rainfall increased over the past two decades at the rate of } 8.033 \mathrm{~mm} \text { per annum. The } \\
\text { monthly maximum temperature showed a positive trend of increase at a rate of } 4.2^{\circ} \mathrm{C} \text { pe } \\
100 \text { years. The maximum increase occurred during October at a rate of } 9{ }^{0} \mathrm{C} \text { per } 100 \text { years } \\
\text { The monthly minimum temperature showed more statistically significant trend of increase } \\
\text { at a rate of } 1.6{ }^{0} \mathrm{C} \text { per } 100 \text { years. The maximum increase occurred during March at a rate of } \\
6.4{ }^{0} \mathrm{C} \text { per } 100 \text { years. Monthly mean temperature showed a positive trend of increase at a } \\
\text { rate of } 2.9^{0} \mathrm{C} \text { per } 100 \text { years. The regression /correlation analysis was used in determining } \\
\text { the trends, the result showed that there was an increase in rainfall and relative humidity in } \\
\text { the month of September and October. Average annual relative humidity data has showed } \\
\text { an increasing trend of } 13.6 \% \text { per } 100 \text { years with correlation coefficient of } 0.45 \text {. The resul } \\
\text { also showed a very high intensity of rainfall and relative humidity in the month of } \\
\text { September of all the years under study with minimum temperature observed in January in } \\
\text { all the years considered for the study. The relative humidity increased as the rainfall } \\
\text { increased. }\end{array}$} \\
\hline & \\
\hline $\begin{array}{l}\text { Coefficient of } \\
\text { variation, } \\
\text { Regression analysis } \\
\text { and trend analysis. }\end{array}$ & \\
\hline Article Info & \\
\hline $\begin{array}{l}\text { Accepted: } \\
\text { 29 September } 2017 \\
\text { Available Online: } \\
10 \text { October } 2017\end{array}$ & \\
\hline & \\
\hline
\end{tabular}

\section{Introduction}

Rainfall variability has major implication on country's economic prosperity. India is predominantly an agricultural country with about $60 \%$ of the cultivated area under rain fed condition. In addition to irrigation and crop planning, rainfall information is also useful for identifying moisture availability period, introduction of new crop in an agroecological region, developing drought characterization index, designing of drainage structure, and devising water harvesting polices ultimately planning for water resources.

In the hydrologic cycle, precipitation plays a vital role and its pattern change would directly influence the water resources of the concerned region. Trend analysis of rainfall will lead to a better understanding of the problems associated with floods, droughts, and the availability of water for various uses with respect to future climate scenarios (Jain 
et al., 2012). Rainfall is the most important characteristic for investigating different hydrological parameters. Forecasting and estimation of rainfall plays an important role particularly in regions where most of the cropped area is unirrigated (Kumara and Kulkari, 2000).

Barman et al., (2012) conducted study on the seasonal and monthly analysis of rainfall data to meet the water demand of different cropping systems. From the probability distribution of seasonal rainfall which indicated that the occurrence of $80 \%$ rainfall in kharif, zaid and rabi season are 751.8, 419.4 and $22.2 \mathrm{~mm}$ respectively, whereas $1193.4 \mathrm{~mm}$ is the annual rainfall, which help in optimizing the choice of crop and its irrigation scheduling. The occurrence of rainy days $(>2.5 \mathrm{~mm}$ rainfall per day) was forecasted i.e. 69 days per annum. Mishra et al., (2013) made a statistical and probability analysis of 40 years daily rainfall data for the period 1971-2010 for crop planning in a canal command and study was carried out on weekly, monthly and annual basis

Gwani et al., (2013) examined the trend and variability of the characteristics of rainfall pattern in relation to relative humidity and maximum temperature and their effect on agricultural production. To determine the trend, regression/correlation analysis were done using monthly rainfall, relative humidity and maximum temperature data of seven years in Sokoto state for the period of 20052011.

Hasan and rahman (2013) analysed the maximum, minimum and average daily temperature data of last sixty-three years (1948-2010), collected from 35 stations of BMD. Trend analysis was performed on monthly average data for all the stations. The monthly maximum, minimum and mean temperature of the country was determined using historic available data from the meteorological stations of Bangladesh.

\section{Materials and Methods}

The study area is Bapatla which is located in $15.8889^{\circ} \mathrm{N}$ latitude, $80.4700^{\circ} \mathrm{E}$ longitude which is $8 \mathrm{~km}$ away from Bay of Bengal, Guntur District of Andhra Pradesh. The average annual rainfall based on observations recorded during 1991 to 2010 is $1078.86 \mathrm{~mm}$. The relative humidity is low in the month of May i.e. about $10 \%$ and is maximum in August i.e., 98\%. Historical weather data for the period from 1991-2010 was collected from the meteorological observatory at Bapatla. The data was divided to monthly, annually and seasonally using Ms excel sheet2010. Three agricultural seasons, viz. zaid/summer (March to May), kharif (June to October) and rabi (November to February) were identified according to cropping systems in this region. The statistical analysis is performed to determine the measure of central tendency (mean) and dispersion (standard deviation and variance) for rainfall data of Bapatla. For identifying the trend in the rainfall data, the linear regression method of statistical analysis is used.

The mean and standard deviation of data of annual rainfall was calculated as follows:

Mean $(\mu)=\sum\left(X_{i} / n\right) \ldots . .(1)$

Standard Deviation $(S D)=\sqrt{ }\left(\left(X_{i}-\mu\right) / n\right) . .(2)$

Where, $X_{i}$ is the annual and seasonal rainfall data in $\mathrm{i}^{\text {th }}$ year $(\mathrm{i}=1,2,3 \ldots \mathrm{n}) ; \mathrm{n}$ is the total number of year of rainfall data to be analysed.

\section{Results and Discussion}

The results of analysis of weather data for Bapatla are discussed. The weather data studied were rainfall, maximum and 
minimum temperature, relative humidity. The region is predominant in agriculture with mostly small scale farmer growing paddy, vegetables and pulses. This analysis would be of more useful for grower of the region.

\section{Analysis of rainfall}

Average annual rainfall of the study area viz. Bapatla during the last two decades (19912010) was arrived as $1078.86 \mathrm{~mm}$ (ranged as $666.66 \mathrm{~mm}$ in 2009 and $1898.4 \mathrm{~mm}$ in 2010) and $60.8 \%$ of which occurred during kharif season itself (June to September), 36.2\% in zaid season (March to May) and 2.9\% in rabi (October to February) season (Table 1). Coefficient of variation in seasonal rainfall was $41.71 \%$ for kharif season, $87.2 \%$ for zaid and $40.9 \%$ for Rabi season. Therefore, cultivation in the rabi season requires assured irrigation.

However, kharif and zaid season cultivation may be carried out under rain fed condition depending upon the water requirement of crops to be cultivated. Marked variation of annual rainfall was observed during the last two decades. However, trend analysis of annual rainfall during 1991 to 2010 revealed that annual rainfall increased over the past two decades at the rate of $8.033 \mathrm{~mm}$ per annum.

As per the standard norms, a day is said to be a rainy day when there is a total rainfall of more than $2.5 \mathrm{~mm} / \mathrm{day}$. This magnitude is fixed as per the farming need. Hence it is of great importance to find out the number of rainy days for crop irrigation scheduling. The number of rainy days varied from 28 to 75 in a year but average was 51 in number. The occurrence of rainfall in the kharif season was $61.8 \%$ followed by rabi season $32.2 \%$ and then zaid season 5.8\%. Among the three seasons, the lowest $\mathrm{C}_{\mathrm{V}}$ for occurrence number of rainy days was found in kharif season
(21\%), followed by rabi season (32\%), but it was found maximum in zaid $(59 \%)$. The lower value of $\mathrm{C}_{\mathrm{V}}$ in kharif and zaid season depicted more consistent occurrence of rainfall and rain days annually whereas higher value of $C_{V}$ inferred that agriculture in Rabi season can still be practiced by depending on residual soil moisture or assured irrigation due to uncertain rainfall. Hence this parameter was analysed and presented for 20 years (Table 1).

The maximum one day rainfall from each year of 20 year data was picked and shown graphically. From the graph, it is evident that 1994, 1995, 1996 shown peak values \& to get the same peak one day rainfall of 1994, i.e. $225 \mathrm{~mm}$, after 13 years, i.e.in 2007 a peak rainfall $250 \mathrm{~mm}$ occurred in the region.

Based on the maximum average concept, mean annual rainfall varied at the value of years after year or in every 4 or 5 years during the study. The data showed that the annual daily maximum rainfall ranged between $71.1 \mathrm{~mm}$ (minimum) to $250.6 \mathrm{~mm}$ (maximum) indicating a very large range of fluctuation during the period of the study.

\section{Analysis of temperature}

\section{Monthly maximum, minimum and mean temperature}

The monthly maximum, minimum and mean temperature of the Bapatla was collected from the meteorological station of Bapatla and presented in Table 4.5. In Fig. 4.9, the monthwise distribution of the average of maximum, minimum and mean temperatures were drawn graphically. The peak value of the maximum temperature was recorded in May 2003 with a magnitude of $47.3^{\circ} \mathrm{c}$ and the minimum temperature was formed in 2008. Moreover, monthly mean temperature was found to be the highest (i.e $32.57^{\circ} \mathrm{C}$ ) during May. 
Monthly trends of daily maximum, minimum and mean temperature

Monthly average rate of temperature during last 20 years (1991-2010) was also studied. A summary of trends ${ }^{0} \mathrm{C}$ monthly maximum and minimum temperature over Bapatla for each month is presented in table 4. Coefficient of determination, $\mathrm{R}^{2}$ of the trends are also presented in Table 4. Coefficient of correlation shown below in table 4 is very poor which cannot be accepted for research study. The Monthly maximum data exhibited a rise of $0.1{ }^{0} \mathrm{C}$ per 100 years during September to $9{ }^{0} \mathrm{C}$ per 100 years during October. On the other hand, the maximum trend of monthly minimum temperature is 6.4 ${ }^{0} \mathrm{C}$ per 100 years in March. The minimum trend of monthly minimum temperature is 0.1 ${ }^{0} \mathrm{C}$ per 100 years in February. It can be clearly found that monthly minimum temperature has been increased significantly during the winter season (October to February) over the last 20 years.

Table.1 Annual and seasonal variability of rainfall ( $\mathrm{mm}$ ) and rainy days (nos) at Bapatla

\begin{tabular}{|c|c|c|c|c|c|c|}
\hline \multirow{2}{*}{ Year } & \multicolumn{2}{|c|}{ Kharif } & \multicolumn{2}{c|}{ Zaid } & \multicolumn{2}{c|}{ Rabi } \\
\cline { 2 - 7 } & Rainfall(mm) & Rainy days & Rainfall(mm) & Rainy days & Rainfall(mm) & Rainy days \\
\hline 1991 & 764.5 & 34 & 8.4 & 1 & 400.5 & 16 \\
\hline 1992 & 476.4 & 31 & 20.4 & 2 & 285.1 & 10 \\
\hline 1993 & 573 & 27 & 86.7 & 4 & 367.1 & 13 \\
\hline 1994 & 323.5 & 24 & 0.6 & 0 & 815.2 & 26 \\
\hline 1995 & 512.4 & 34 & 193.3 & 5 & 388.4 & 13 \\
\hline 1996 & 719.2 & 38 & 14.4 & 2 & 500.2 & 21 \\
\hline 1997 & 662.9 & 27 & 114.2 & 4 & 341 & 25 \\
\hline 1998 & 685.1 & 32 & 25.1 & 1 & 508.9 & 23 \\
\hline 1999 & 492.1 & 32 & 109.8 & 3 & 230.4 & 17 \\
\hline 2000 & 908.7 & 34 & 45.5 & 3 & 168.3 & 8 \\
\hline 2001 & 604.3 & 32 & 152.9 & 4 & 384.8 & 20 \\
\hline 2002 & 403.2 & 30 & 25 & 2 & 358.2 & 13 \\
\hline 2003 & 602.1 & 40 & 6.2 & 1 & 343.7 & 17 \\
\hline 2004 & 436.4 & 24 & 100.9 & 5 & 174.9 & 11 \\
\hline 2005 & 578 & 31 & 14.3 & 3 & 422.7 & 19 \\
\hline 2006 & 444 & 30 & 186.1 & 7 & 565.5 & 14 \\
\hline 2007 & 1125.3 & 35 & 31.4 & 3 & 235.8 & 17 \\
\hline 2008 & 582.8 & 32 & 110.7 & 6 & 381.7 & 11 \\
\hline 2009 & 486.9 & 16 & 23.2 & 1 & 156.5 & 11 \\
\hline 2010 & 1232.5 & 48 & 149.5 & 3 & 516.4 & 24 \\
\hline Mean & $\mathbf{6 3 0 . 6 6}$ & $\mathbf{3 1 . 5 5}$ & $\mathbf{7 0 . 9 3}$ & $\mathbf{3}$ & $\mathbf{3 7 7 . 2 7}$ & $\mathbf{1 6 . 4 5}$ \\
\hline SD* & $\mathbf{2 6 3 . 5 3}$ & $\mathbf{6 . 3 9}$ & $\mathbf{6 1 . 8 9}$ & $\mathbf{1 . 7 8}$ & $\mathbf{1 5 2 . 9 9}$ & $\mathbf{5 . 2 4}$ \\
\hline CV*(\%) & $\mathbf{4 2}$ & $\mathbf{2 1}$ & $\mathbf{8 7 . 2}$ & $\mathbf{5 9}$ & $\mathbf{4 1}$ & $\mathbf{3 2}$ \\
\hline SD & & & & & \\
\hline
\end{tabular}

$* \mathrm{SD}=$ Standard deviation, $\mathrm{CV}=$ coefficient of variation

\begin{tabular}{|c|c|c|c|c|c|}
\hline \multicolumn{7}{|c|}{ Seasonal Rainfall Analysis } \\
\hline \multicolumn{3}{|c|}{ Rainfall(in mm) } & \multicolumn{3}{c|}{ Rainy day(no.s) } \\
\hline SD $_{\max }$ & Max & Min & SD $_{\max }$ & Max & Min \\
\hline 263.53 (Kharif) & 1232.5 (Kharif) & 0.6 (Zaid) & 6.39 (Kharif) & 48(Kharif) & 0 (Zaid) \\
\hline
\end{tabular}


Table.2 Statistics of mean monthly rainfall at Bapatla (1991-2010)

\begin{tabular}{|c|c|c|c|c|c|c|}
\hline Month & $\begin{array}{c}\operatorname{Maximum}(\mathbf{m m}) \\
(\mathbf{m m})\end{array}$ & $\begin{array}{l}\text { Minimum(mm) } \\
\text { 0)(mm) }\end{array}$ & $\begin{array}{c}\operatorname{Mean}(\mathbf{m m}) \\
(\mathbf{m m})\end{array}$ & $\begin{array}{l}\text { SD(mm) } \\
(\mathbf{m m})\end{array}$ & $\operatorname{Variance}\left(\sigma^{2}\right)$ & CV $(\%)$ \\
\hline January & 138.3 & 0 & 13.97 & 33.65 & 1132.44 & 240.97 \\
\hline February & 86.4 & 0 & 10.13 & 22.97 & 527.43 & 226.82 \\
\hline March & 95.7 & 0 & 6.61 & 21.92 & 480.58 & 331.90 \\
\hline April & 151.7 & 0 & 19.57 & 40.59 & 1647.71 & 207.47 \\
\hline May & 193.1 & 0.2 & 44.76 & 56.00 & 3135.95 & 125.11 \\
\hline June & 382.2 & 16 & 106.70 & 94.40 & 8910.65 & 88.47 \\
\hline July & 122.6 & 0 & 18.96 & 29.19 & 852.06 & 154 \\
\hline August & 431 & 29.2 & 182.94 & 106.55 & 11353.81 & 58.25 \\
\hline September & 362.5 & 53.7 & 212.18 & 107.70 & 11599.69 & 50.76 \\
\hline October & 474.3 & 3.6 & 217.04 & 141.17 & 19928.75 & 65.04 \\
\hline November & 430 & 0 & 104.47 & 110.87 & 12291.47 & 106.12 \\
\hline December & 170.3 & 0 & 31.81 & 64.05 & 4102.67 & 201.36 \\
\hline
\end{tabular}

\begin{tabular}{|c|c|c|c|c|c|}
\hline \multicolumn{7}{|c|}{ Monthly rainfall analysis } \\
\hline Mean(mm) & $\mathbf{S D}_{\max }(\mathbf{m m})$ & $\mathbf{S D}_{\min }(\mathbf{m m})$ & $\mathbf{M a x}(\mathbf{m m})$ & $\mathbf{C V}_{\max }(\boldsymbol{\%})$ & $\mathbf{C V}_{\min }(\boldsymbol{\%})$ \\
\hline 80.76 & $141.17(\mathrm{Oct})$ & $21.92(\mathrm{Mar})$ & $474.3(\mathrm{Oct})$ & $331.90(\mathrm{Mar})$ & $50.76(\mathrm{Sep})$ \\
\hline
\end{tabular}

Table.3 Statistical analysis of yearly rainfall data from 1991 -2010 (Bapatla)

\begin{tabular}{|c|c|c|c|c|}
\hline \multicolumn{5}{|c|}{ Yearly Rainfall Analysis } \\
\hline Mean(mm) & Max(mm) & Min(mm) & SD(mm) & CV (\%) \\
\hline 1078.86 & $1898.4(2010)$ & $666.6(2009)$ & 272.36 & 25 \\
\hline
\end{tabular}

Table.4 Monthly average trends and $\mathrm{R}^{2}$ value of monthly maximum and minimum temperature during last 20 year period (1991-2010)

\begin{tabular}{|l|l|c|c|c|c|}
\hline \multirow{2}{*}{ S NO. } & \multirow{2}{*}{ Month } & \multicolumn{4}{|c|}{ Average of 20 years period(1991-2010) } \\
\cline { 3 - 6 } & & Max & $\mathbf{R}^{\mathbf{2}}$ & Min & $\mathbf{R}^{\mathbf{2}}$ \\
\hline 1. & January & 0.0526 & 0.245 & 0.016 & 0.009 \\
\hline 2. & February & 0.034 & 0.134 & 0.001 & 0.00006 \\
\hline 3. & March & 0.029 & 0.149 & 0.064 & 0.156 \\
\hline 4. & April & 0.051 & 0.131 & 0.042 & 0.105 \\
\hline 5. & May & 0.082 & 0.081 & 0.001 & 0.000 \\
\hline 6. & June & 0.082 & 0.081 & 0.010 & 0.005 \\
\hline 7. & July & 0.025 & 0.008 & 0.008 & 0.004 \\
\hline 8. & August & 0.029 & 0.018 & 0.002 & 0.001 \\
\hline 9. & September & 0.001 & 0.00009 & 0.009 & 0.026 \\
\hline 10. & October & 0.090 & 0.450 & 0.009 & 0.037 \\
\hline 11. & November & 0.037 & 0.109 & 0.008 & 0.002 \\
\hline 12. & December & 0.046 & 0.188 & 0.059 & 0.105 \\
\hline & Average & 0.0465 & 0.1328 & 0.0191 & 0.0375 \\
\hline
\end{tabular}


Fig.1 Variation of seasonal rainfall distribution for a period from 1991 -2010

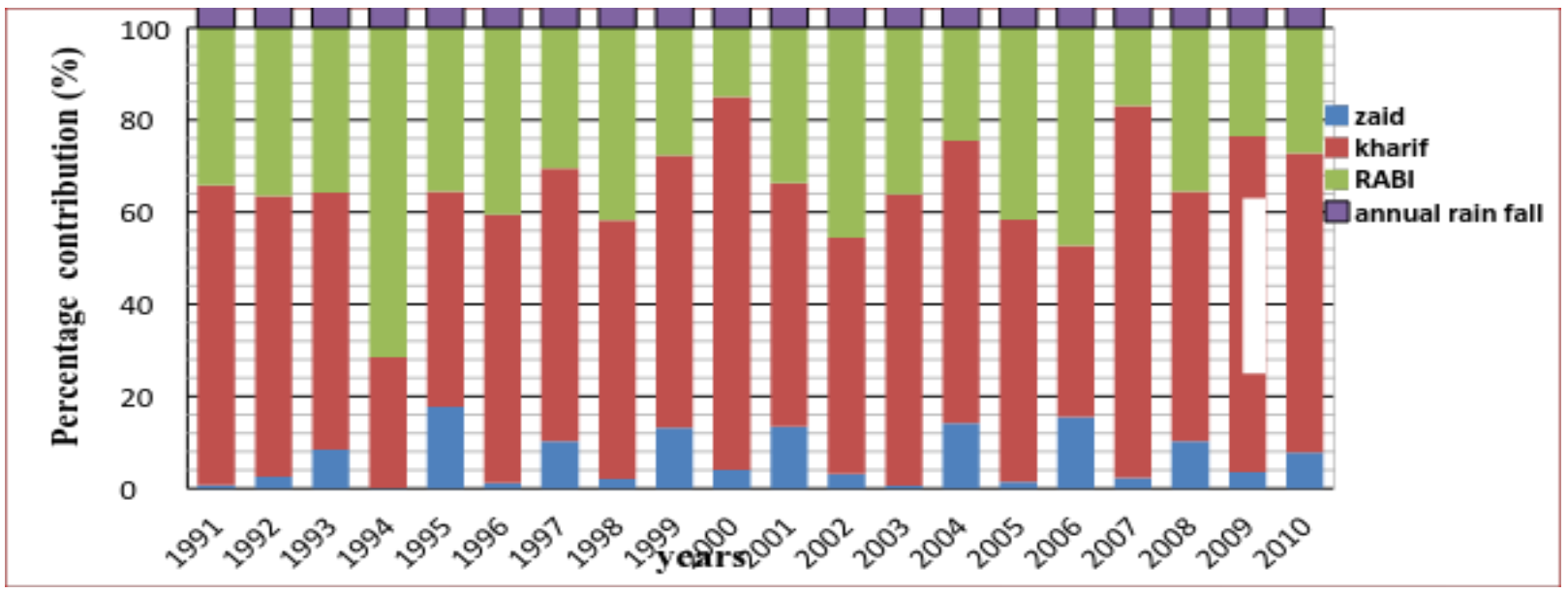

Fig.2 Year wise annual maximum daily of Bapatla from 1991- 2010

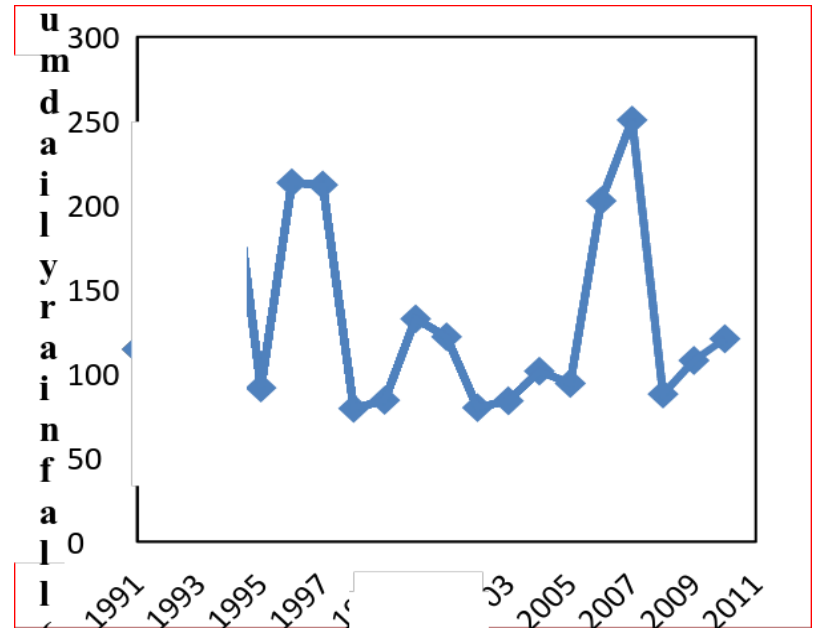

Fig.3 Trend of annual rainfall during rainfall 1991-2010 at Bapatla

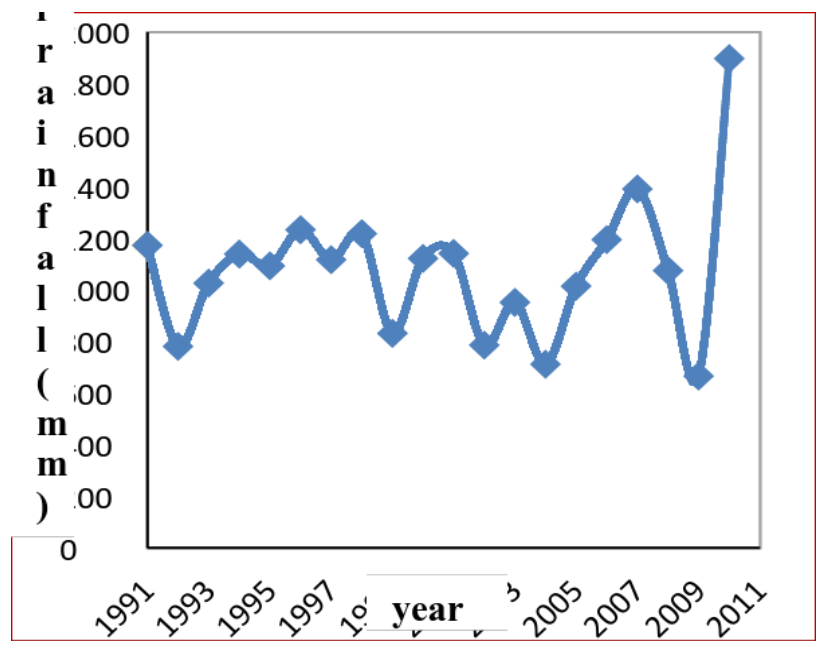


Fig.4 Monthly distribution of rainfall and rainy day at Bapatla

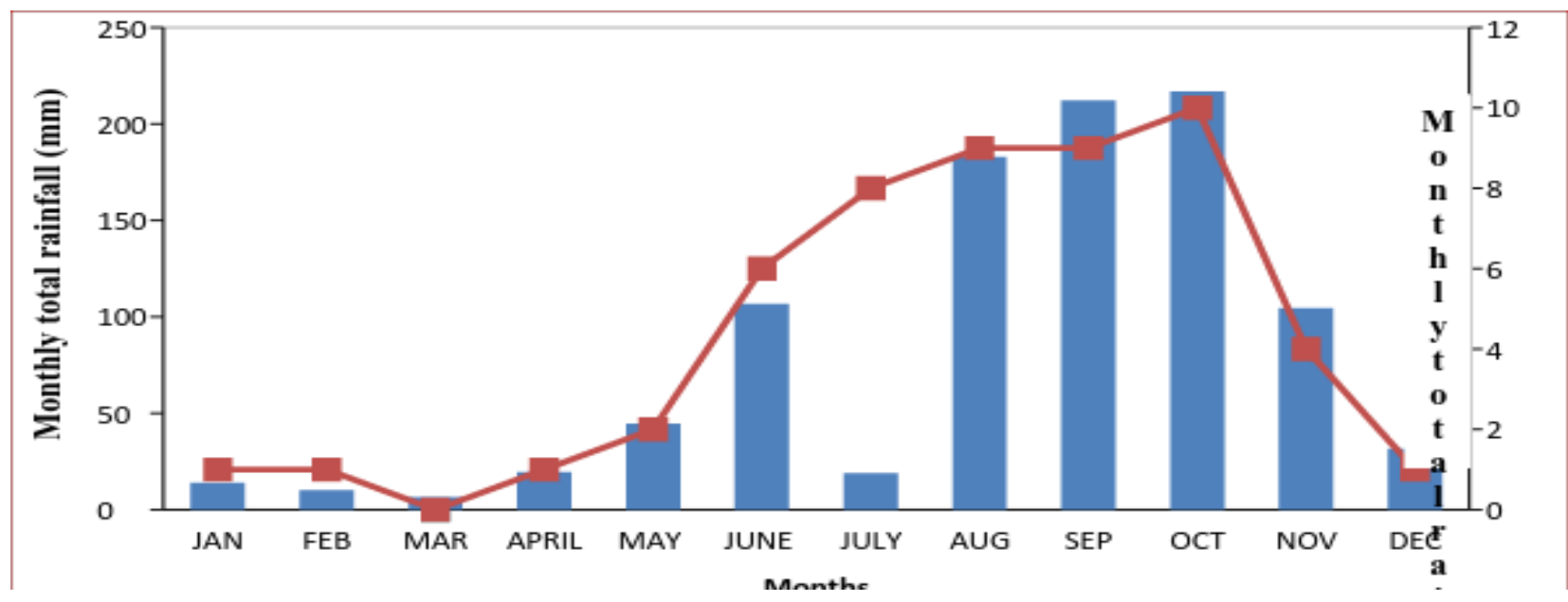

Fig.5 Histogram showing monthly average of maximum, minimum and mean temperature $\left({ }^{\circ} \mathrm{C}\right)$ during the last twenty years period (1991-2010)

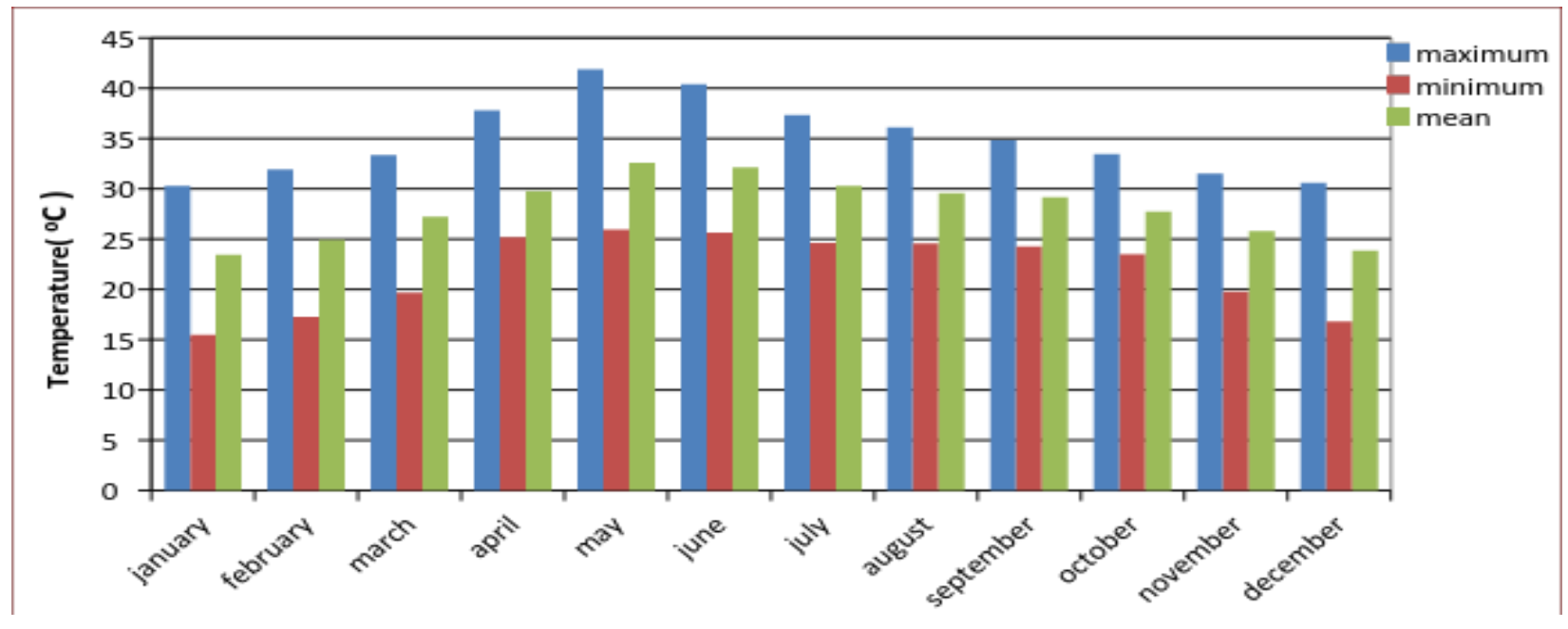

Fig.6 Trend of the monthly maximum temperature of Bapatla (1991-2010) where correlation coefficient $r=0.53$

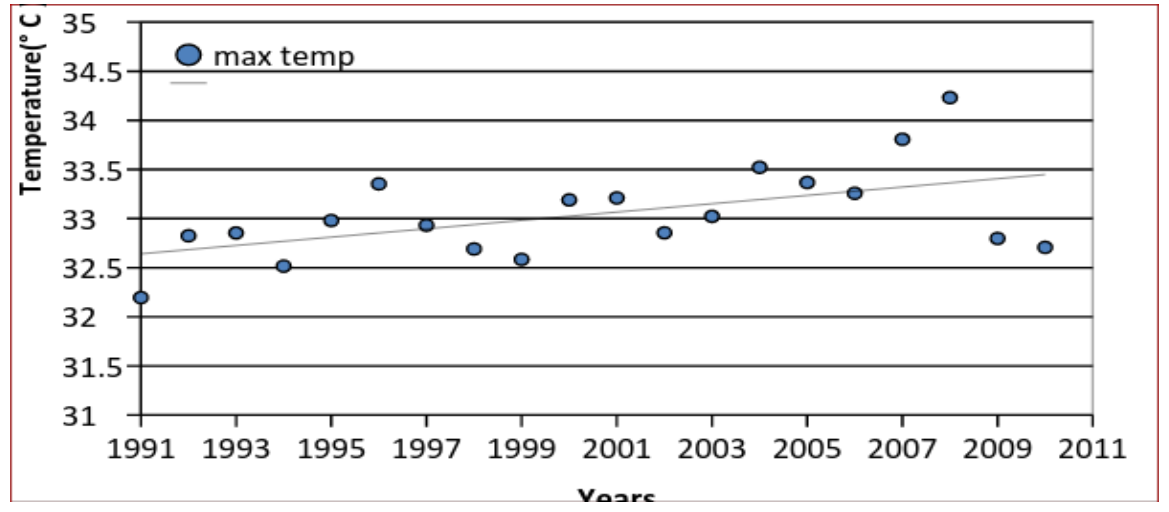


Fig.7 Trend of the monthly minimum temperature of Bapatla (1991-2010) where correlation coefficient $r=0.23$

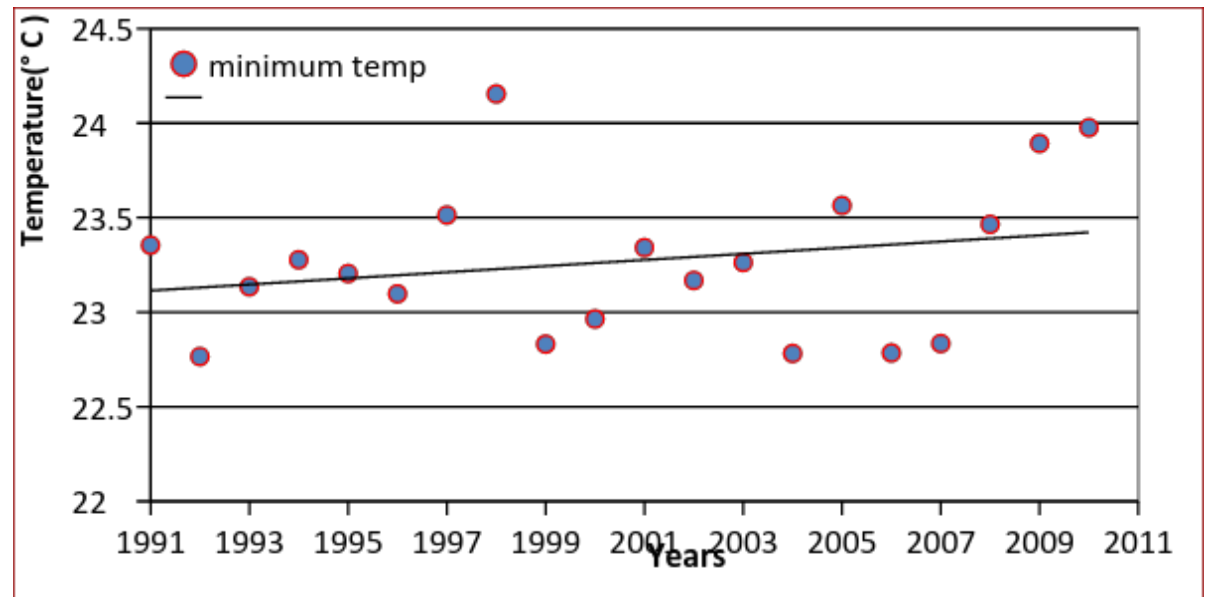

Fig.8 Trend of the monthly mean temperature of the Bapatla (1991-2010) where correlation coefficient $r=0.63$

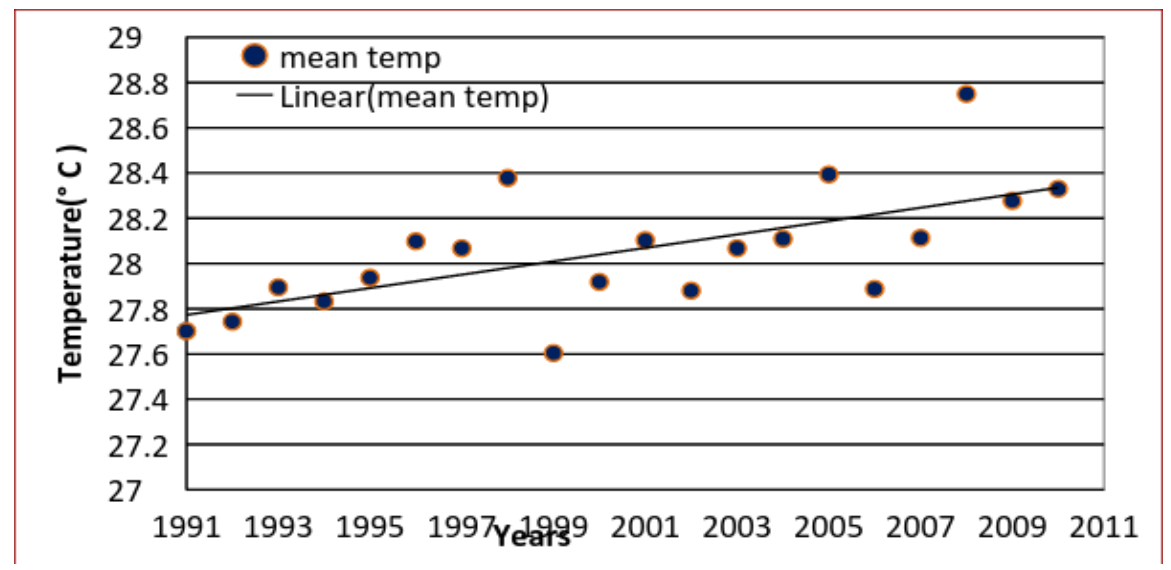

Fig.9 Average annual extreme temperatures throughout recording period of Bapatla (1991-2010)

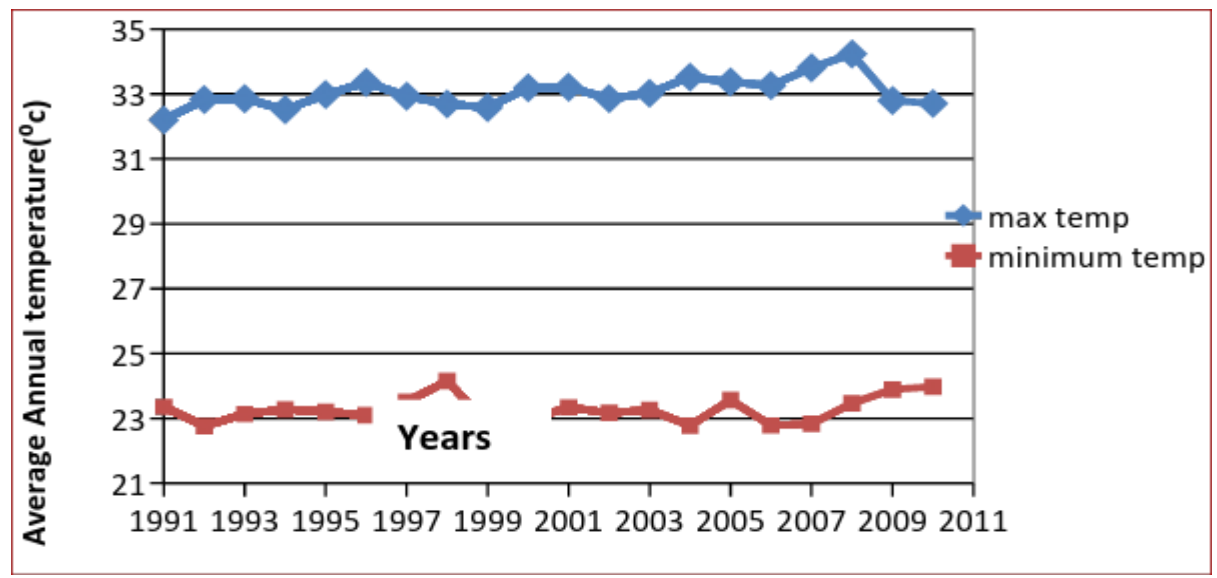


Fig.10 Shows monthly rainfall, mean relative humidity and mean temperature of years 1992, 2000, 2004, 2006, 2008 and 2010 respectively

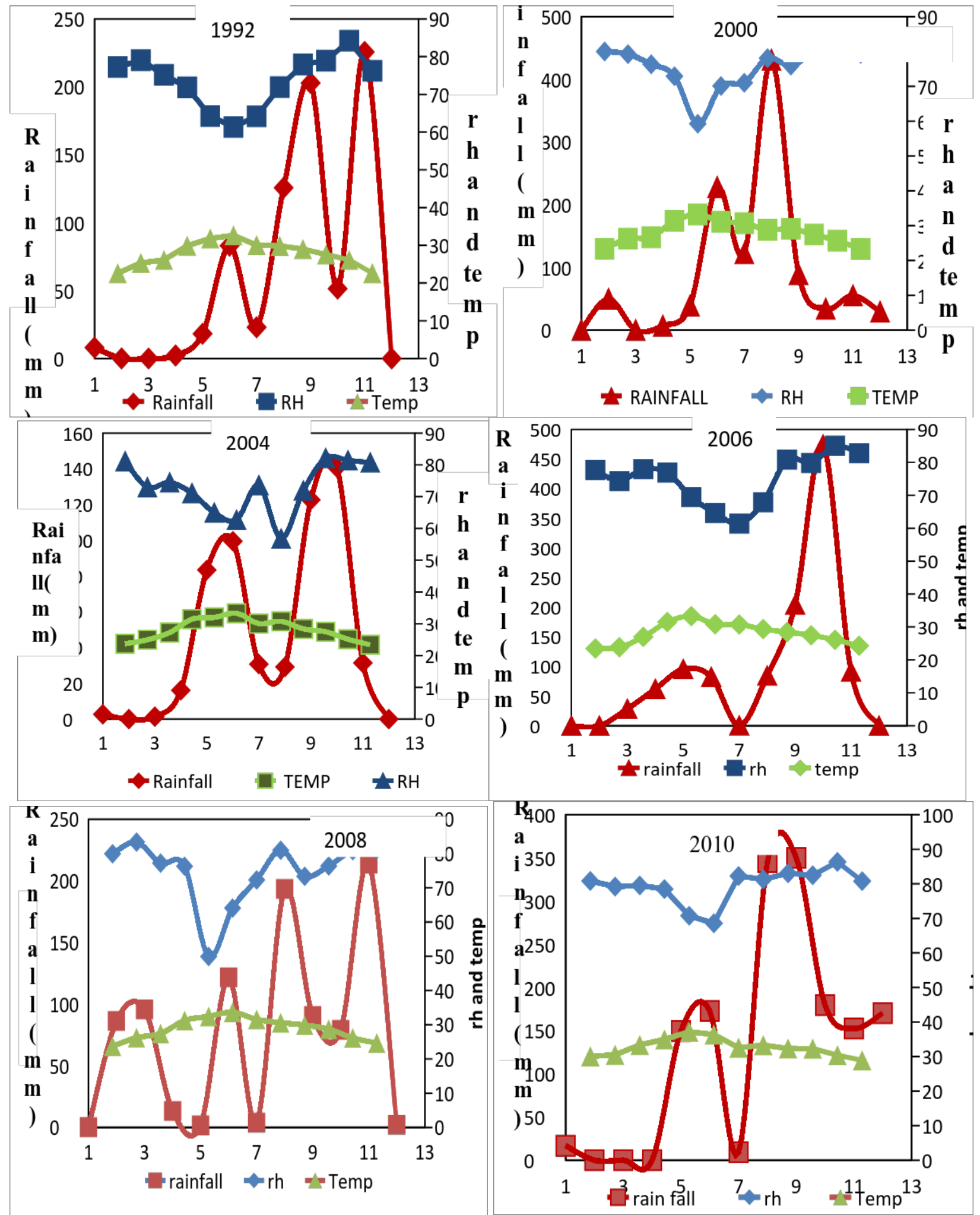


Fig.11 Variation of mean yearly rainfall \& relative humidity in Bapatla (1991-2010)

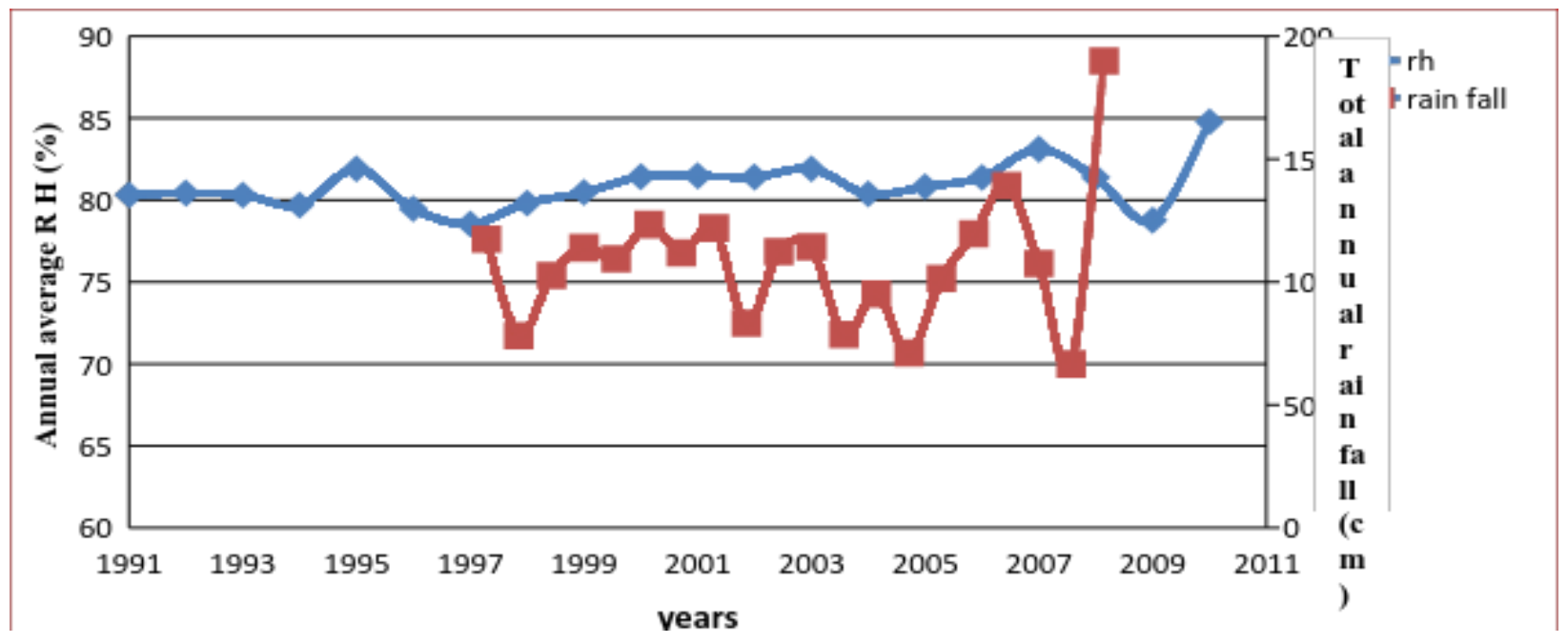

In this study, trends of monthly (from average of daily) temperature data were analysed during the period 1991-2010. Monthly maximum temperature data had shown an increasing trend of $4.2^{\circ} \mathrm{C}$ per 100 years $\mathrm{On}$ the other hand, monthly minimum temperature had increased with a rate of data $1.6^{\circ} \mathrm{C}$ per 100 years with in Fig 7. Also, monthly mean temperature data had exhibited more statistically significant trend of $2.9^{\circ} \mathrm{C}$ per 100 years with correlation coefficient (figure 8).

\section{Trends of monthly (from average of daily)} maximum, minimum and mean temperature

\section{Analysis of relative humidity}

From Fig 10, it could be observed that the month of July mark the beginning of rainfall over the years. The rainfall duration was observed to be five months. Rainfall was observed to end in November (Figure 10). The rainfall intensity was observed to be high in the month of September and October of all the years considered for study. The peak rainfall was recorded in the month of October of all the years. The relative humidity is observed to increase during the month of May to September (Figure 10). When the rainfall is considerably high; the peak relative humidity was obtained in the month of August in all the years considered for the study. It was observed in 1993 with a magnitude of 98 and the minimum relative humidity was obtained in 2008 with a magnitude of 10.The temperature on the other hand showed a similar pattern (from fig. 10), in all the years under study period.

The temperature was observed to increase from the month of January to April and decrease in the month of May just when the rainfall began, it decreases to its of minimal in the month of August when the rainfall and relative humidity was observe to be very high. The temperature eventually increases in the month of November and December where there is no rainfall at all. This study showed that there is a significant increase in annual rainfall amount mostly in the month of July and October with the highest amount of rainfall observed in the month of August except in 2008 where the maximum rainfall was recorded in July. The plot also revealed that the maximum temperature decreased to its minimum when the amount of rainfall and relative humidity, both at their maximum, which indicates that the amount of rainfall and relative humidity but are interdependent.

The yearly correlation between the rainfall and relative humidity of the study area from 19912010 is shown in fig. 11, indicating the year 
with the highest rainfall and relative humidity. From the figure it is evident that there is a direct relationship between rainfall and relative humidity throughout the months of the year. The rainfall increases as the relative humidity increase. Average annual relative humidity data have shown an increasing trend of $13.6 \%$ per 100 years with correlation coefficient of 0.45 as shown in Figure 11.

The agro-climatic information is most useful for crop planning and solving of practical agricultural problems. Without such analysis, the adoption of farming system or planning an agronomic technology to an area might be unsuccessful. In the present study, analysis of weather data of Bapatla from 1991 to 2010 were carried out to assist farmer for better irrigation planning, irrigation scheduling, crop selection etc. The annual daily maximum rainfall received at any time ranged between $71.1 \mathrm{~mm}$ (minimum) to $250.6 \mathrm{~mm}$ (maximum) during the period of study, which was recorded in the month of October of all the years. So, for cultivation of the crop proper drainage system should be there taking it into consideration.

The total rainfall in the Kharif season was $61.8 \%$ followed by Rabi season $32.2 \%$ and then zaid season $5.8 \%$ of the total annual rain fall with a mean seasonal of rainfall $631 \mathrm{~mm}$, $377 \mathrm{~mm}$ and $71 \mathrm{~mm}$ respectively. The relative humidity is observed to increase during the month of May to September, when the rainfall is considerably high, the peak relative humidity was obtained in the month of August in all the years considered for the study.

\section{Acknowledgement}

The authors, acknowledges the Meteorological department of Bapatla for providing weather data of the station due which this study have been made possible. The authors also sincerely acknowledge the support of CAE, BAPATLA for supporting during the study.

\section{References}

Barman, D., Saha, A.R., Kundu, D.K. and Mahapatra, B.S. 2012. Rainfall Characteristics Analysis for Jute based Cropping System at Barrackpore, West Bengal, India, and Journal of Agricultural Physics. Vol. 12: 23-28.

Gwani, M.G., Abubakar, G.A., Fatigue, A.T., Adebiyi, S. J. and B Joshua. 2013. Analysis of Monthly Variation of Relative Humidity and Temperature of Sokoto, Nigeria, World Journal of Engineering and Pure and Applied Science. Vol. 3: 12 -15.

Hasan, A.B.M., Shamim Ul and Rahman, M.Z. 2013. Change in Temperature over Bangladesh Associated with Degrees of Global Warming, Asian Journal of Applied Science and Engineering, Vol. 2: 62-75

Jain, S.K., and Kumar, V. 2012. Trend analysis of rainfall and temperature data for India, Current science. Vol. 102(1):37-49.

Kumari, S., G.K. and Kulkarani, S. 2000. Forecasting rainfall in Andhra Pradesh. Proc. International Conference on Managing Water Resources for sustainable Agricultural Production in the 21st Century. New Delhi: 609-612.

Mishra, P.K., Khare, D., Mondal, A., Kundu, S. and Shukla, R. 2013. Statistical and Probability Analysis of Rainfall for Crop Planning in a Canal Command, Agriculture for Sustainable Development: 95-102.

\section{How to cite this article:}

Saurav Srichandan Dash and Hema Kumar, H.V. 2017. Statistical and Trend Analysis of Climate Data of Bapatla (A.P), India. Int.J.Curr.Microbiol.App.Sci. 6(10): 4959-4969.

doi: https://doi.org/10.20546/ijcmas.2017.610.470 